\title{
Experimental Investigation on the Properties of Recycled Concrete Using Hybrid Fibers
}

\author{
Salim Khoso, Janet Raad, Azadeh Parvin \\ Department of Civil and Environmental Engineering, The University of Toledo, Toledo, OH, USA \\ Email: salim.khoso@rockets.utoledo.edu, Janet.Raad@rockets.utoledo.edu, azadeh.parvin@utoledo.edu
}

How to cite this paper: Khoso, S., Raad, J. and Parvin, A. (2019) Experimental Investigation on the Properties of Recycled Concrete Using Hybrid Fibers. Open Journal of Composite Materials, 9, 183-196. https://doi.org/10.4236/ojcm.2019.92009

Received: January 25, 2019

Accepted: April 13, 2019

Published: April 16, 2019

Copyright ( 2019 by author(s) and Scientific Research Publishing Inc. This work is licensed under the Creative Commons Attribution International License (CC BY 4.0).

http://creativecommons.org/licenses/by/4.0/ (c) (i) Open Access

\begin{abstract}
Due to the inherent property of concrete being very weak in tension, efforts have been made to overcome this deficiency by adding various type of fibers like carbon fiber reinforced polymer (CFRP), glass fiber reinforced polymer (GFRP), polypropylene fiber (PPF) and stainlesssteel fiber (SSF) smeared into the concrete mix. The present study involves experimental investigation on the use of GFRP, CFRP and SSF fibers alone or as combination to improve the mechanical properties of concrete. Furthermore, concrete cylinders were cast and tested for compression and tension using $10 \%$ fly ash as cement replacement in all specimens. Besides fiber material types, fiber reinforcement ratios of $1 \%$ and $1.5 \%$ were tested to investigate the mechanical properties of concrete. In all concrete cylinder tests, the fiber reinforcement ratio of $1 \%$ had a significant contribution in increasing the tensile strength as oppose to compressive strength. As a result, the tensile and compressive strengths were increased by $26 \%$ and $11 \%$, respectively as compared to the control specimen. Increasing the fiber reinforcement ratio from $1 \%$ to $1.5 \%$, resulted in diminishing the mechanical properties of concrete. However, reduction in concrete compressive strength was more prominent than the tensile strength. Furthermore, it was observed that, the crack propagation was decreased with the increase of fiber content when compared to the control specimen.
\end{abstract}

\section{Keywords}

Fiber-Reinforced Concrete, Fly-Ash, Compressive Strength, Tensile Strength, Carbon Fiber, Glass Fiber, Stainless Steel Fiber

\section{Introduction}

Demand of using fiber reinforced polymer (FRP) materials has been increased widely thorough out the world in the past few decades. FRP materials have nu- 
merous applications, including transportation and construction projects. The composites industry is now producing a wide range of FRP products such as strips, sheets, laminates, bars, pultruded members, sandwich panels and piping. In addition to recycled materials i.e. silica fume, fly ash, blast furnace slag and baggase ash that are used as cement replacement in concrete mix, smeared fibers can also improve the mechanical properties of cement concrete. Fiber reinforced concrete (FRC) is basically made of hydraulic cements, aggregates, and discrete reinforcing fibers. Suitable reinforcing fibers for concrete include steel, and organic or synthetic fibers. Concrete mixture consists of cement, sand and aggregates normally proportioned in different ratios based on particular applications. Fiber reinforced polymer can be added to the concrete mix to improve long-term serviceability of reinforced concrete (RC) structures if the mix is properly designed (ACI Committee 544 report). The addition of fibers in concrete reduces crack width, thus increasing the durability of the concrete structures. As compared to normal strength concrete, fiber-reinforced concrete is much stronger and more resistant under extreme loading and enhances the energy absorption capability and stiffness of the material. However, it also increases the tensile as well as the flexural strength of concrete. To reduce the impact on the environment and to reduce the cost, recycled materials are used as substitutes for cement in the concrete mix. The recycled waste materials consist of silica fume (SF), fly ash (FA), blast furnace slag (BFS), rice husk ash (RHA) and sugarcane baggase ash (SCBA). The engineering advantages of mixing fiber in cement concrete improve the stiffness, fracture, fatigue resistance, flexural strength, compressive strength, impact resistance, thermal crack resistance, and shear strength. The improvement in such properties depends both upon the amount and the type of fiber used [1]. Addition of fibers in concrete increases the mechanical properties such as compressive strength, split tensile strength and flexural strength up to a considerable limit [2] [3]. They also found that upto some extent fiber was effective giving noticeable increase in strengthening the mechanical properties of concrete. However, further increase in fiber content was found to be ineffective. Addition of fibers in higher volume fractions reduces the workability of concrete mix [4] [5] [6]. Plain concrete is a brittle material and fails suddenly. Adding fibers to cement concrete mix changes its brittle mode of failure into a more ductile one and improves the concrete ductility. In the work carried out [3], it was observed that a slow propagation of crack occurred in fiberly reinforced as compared with the traditional concrete, which indicated a ductile failure mode in fiber reinforced concrete, whereas the quick propagation of crack in plain concrete showed brittle failure. Other than fibers, supplementary cement materials are incorporated or at the same time replaced with cement. Karahan [7] worked on the durability properties of concrete containing polypropylene fiber and fly ash. According to his experimental investigations, addition of fiber in concrete and fly ash as cement replacement reduced the density of concrete. However, incorporating fly ash in concrete improved the workabili- 
ty which was decreased by addition of polypropylene fiber. Moreover, freeze and thaw resistance of polypropylene fiber concrete was found to slightly increase when compared to concrete without fibers. Furthermore, it was also investigated that fly ash increased the freeze and thaw resistance more than the polypropylene fibers did. Freeze and thaw resistance of fiber-reinforced concrete increased with increasing with fly ash content. Addition of supplementary material on concrete increases the mechanical properties. Optimum replacement of cement by supplementary materials like silica fume and fly ash improved the mechanical properties of concrete. Moreover, the use of silica fume and fly ash not only improve the various properties of concrete but could also be economical and cost solution in the construction industry [7] [8] [9]. Use of hybrid fibers with different proportions in concrete mix along with supplementary materials as cement replacement has been found more effective in enhancing the mechanical properties of concrete. Hybrid fibers have contributed in improving the compressive and split tensile strength of concrete [10]. Supplementary cement replacement materials have played vital role in improving the compressive strength however fibers contributed in enhancing the split tensile strength of concrete [11] [12]. Other than the mechanical properties of concrete, the modulus of rupture of concrete with fibers have been found much improved as compared with other counterparts. Moreover, on the impact resistance, the first-crack and failure strengths and the percentage increase in the post first-crack blows found improved in concrete with fibers than for other concrete specimens. In addition, the shrinkage crack reduction potential is also improved in concrete made with fibers [13] [14].

The further information regarding the supplementary material used in this experimental work is explained as follow.

\section{Fly Ash}

Fly ash is a residue generated from burning pulverized coal in electric coal power generating plants. During the process of combustion, mineral impurities in the coal such as quartz, clay, feldspar, and shale, fuse in suspension and float out of the combustion chamber with the exhaust gases. As the fused material rises, it becomes cool resulting in the solidification of glassy spherical particles known as fly ash. Fly ash is collected from the exhaust gases, and the obtained fine powder resembles with ordinary Portland cement with some different chemical properties. Fly ash reacts similarly like cement with the residue calcium hydroxide released by the chemical reaction between cement and water to form additional cementitious products improving many desirable properties of concrete. The chemical reaction between fly ash and calcium hydroxide typically is slower resulting in delayed hardening of the concrete when compared to the one with cement and water. Two types of fly ash are commonly used in concrete: Class C and Class F. Class $\mathrm{C}$ are often high-calcium fly ashes with carbon content less than $2 \%$; whereas, Class $\mathrm{F}$ are generally low-calcium fly ashes with carbon con- 
tents less than $5 \%$ but sometimes as high as $10 \%$. In general, Class $\mathrm{C}$ ashes are produced from burning sub-bituminous or lignite coals and Class $\mathrm{F}$ ashes bituminous or anthracite coals. Performance properties between Class $\mathrm{C}$ and $\mathrm{F}$ ashes vary depending on the chemical and physical properties of the ash and how the ash interacts with cement in the concrete. Many Class $\mathrm{C}$ ashes when exposed to water will react and become hard just like cement, but not Class $\mathrm{F}$ ashes. Most, if not all, Class $\mathrm{F}$ ashes will only react with the byproducts formed when cement reacts with water [15]. Class F fly ash was used in this research work.

\section{Present Investigation}

In the present work, fibers ranging in 15 to $25 \mathrm{~mm}$ in length are used in preparing concrete made with fly ash replacing cement by $10 \%$. Fibers act as a secondary reinforcement mainly to contribute in improving both compressive and tensile properties of concrete. Fly ash used during this research study was obtained from Kuhlman corporation in Toledo area, which is mainly the byproduct or the residual of coal. Concrete specimens were prepared for the age of 28 days where almost the required strength is achieved. In this research work, an effort has been made to obtain the optimum strength of concrete by smearing hybrid fibers and replacing cement with fly ash. Utilization of such supplementary materials will not only contribute in increasing concrete properties, however, may be economically fit for constructions in many countries. This could create further business opportunities, save energy by recycling different by products created from various industries and could also conserve the diminishing resources of traditional aggregates.

\section{Materials, Methodology and Experimental Program}

\subsection{Materials}

\subsubsection{Cement}

Ordinary Portland cement (OPC) was used in preparing all concrete specimens. Cement used during this work was freshly made and recently purchased ensuring that the cement used was not old or expired. Physical tests of cement were also conducted the details of which are given in Table 1 .

\subsubsection{Fly Ash}

Fly ash used in this experimental work was obtained from Kuhlman corporation situated in the vicinity of Toledo in Ohio. The chemical composition of cement and fly ash is shown in Table 2.

\subsubsection{Coarse and Fine Aggregate}

Locally available course aggregate material was used in preparation of all concrete specimens. Water absorption test for course aggregate was conducted for 24 hours and was found the aggregate absorbed water only 1 percent. Similarly, locally available river sand was used as fine aggregate. Sieve analysis was conducted for both materials and was brought to the required size. Tests regarding 
the specific weight and water absorption for coarse aggregate was conducted, the details of which are shown in Table 3.

\subsubsection{Mixing Water}

Potable water was used in the concrete mix during preparation of specimens. The potable tape water from the concrete lab of the University of Toledo was tested which gave an average $\mathrm{pH}$ value of 7.1. Therefore, the tape water was found fit for our experimental work.

\subsubsection{Fibers Used}

Three different fibers, carbon fiber reinforced polymer (CFRP), glass fiber reinforced polymer (GFRP) and stainless steel fiber (SSF) were used during this experimental work. GFRP and CFRP were obtained from Owens Corning Toledo, Ohio, whereas stainless steel fibers (SSF) were attained from mechanical department workshop at the University of Toledo. The size of all mentioned fibers was in the range of 15 to $25 \mathrm{~mm}$ in length.

\subsection{Methodology}

All the specimens cast were done by following ASTM standards and the ratio for cement, fine aggregate and coarse aggregate used was 1:2:4. Dimensions of cylinder specimens were $150 \mathrm{~mm}$ in diameter with height of $300 \mathrm{~mm}$. The procedure was done in three different phases the detail of which is given under. After preparing the control concrete specimens, cement was replaced by $10 \%$ of fly ash and $1 \%$ of fibers by weight of cement which was smeared in concrete mix. After curing of 28 days, cylinders were tested for compressive as well as split tensile strengths [16] [17] [18].

\subsection{Experimental Work \& Tests}

The experimental work during this research activity was carried out in the concrete laboratory of civil engineering department at the university of Toledo, Ohio. Different tests regarding concrete and sand were conducted the details of which are given as under [19] [20] [21].

\subsubsection{Slump Test}

Slump test was conducted for all the batches of mix design. The results of which are given in Table 4.

\subsubsection{Fineness Modulus of Sand}

One $\mathrm{Kg}$ of sand was used to perform the sieve analysis as per ASTM C33. The fineness modulus of sand was calculated using the given equation;

$$
\begin{aligned}
& \text { Fineness Modulus(FM) } \\
& =\frac{\sum \text { Cumulative Weight Percentage Retained on Each Sieve }}{100}
\end{aligned}
$$

The results of sieve analysis and fineness modulus are given in Table 5. Sieve analysis and fineness modulus of sand. 
Table 1. Physical test results of cement.

\begin{tabular}{ccc}
\hline S.NO. & TESTS & RESULTS \\
\hline 1 & Specific gravity & 3.5 \\
2 & Consistency & $28 \%$ \\
3 & Initial setting time & 30 minutes \\
4 & Final setting time & 600 minutes \\
\hline
\end{tabular}

Table 2. Chemical composition of cement and fly ash.

\begin{tabular}{cccccccccc}
\hline Oxide & $\mathrm{SiO}_{2}$ & $\mathrm{Al}_{2} \mathrm{O}_{3}$ & $\mathrm{Fe}_{2} \mathrm{O}_{3}$ & $\mathrm{CaO}$ & $\mathrm{MgO}$ & $\mathrm{SO}_{3}$ & $\mathrm{~K}_{2} \mathrm{O}$ & $\mathrm{Na}_{2} \mathrm{O}$ & LOI \\
\hline Cement & 19.71 & 5.2 & 3.73 & 62.91 & 2.54 & 2.72 & 0.9 & 0.25 & 0.96 \\
Fly Ash & 52.5 & 22.82 & 5.34 & 7.16 & 2.56 & 0.2 & 0.99 & 0.48 & 3.35 \\
\hline
\end{tabular}

Table 3. Test results of recycled aggregates.

\begin{tabular}{ccc}
\hline S. No. & Tests & Recycled aggregates \\
\hline 1 & Specific gravity & 2.8 \\
2 & Water absorption & $1 \%$ \\
\hline
\end{tabular}

Table 4. Slump cone test results of different concrete mix. Fineness modulus of sand.

\begin{tabular}{ccccc}
\hline Batch & Concrete type & Mix design ratio & W/c ratio & Slump \\
\hline 1 & Control specimen & $1: 2: 4$ & 0.5 & $30 \mathrm{~mm}$ \\
2 & $\begin{array}{c}10 \% \text { Cement replacement with FA } \\
\text { \& addition of CFRP }\end{array}$ & $1: 2: 4$ & 0.5 & $15 \mathrm{~mm}$ \\
3 & $\begin{array}{c}10 \% \text { Cement replacement with FA } \\
\text { \& addition of CFRP + GFRP }\end{array}$ & $1: 2: 4$ & 0.5 & $10 \mathrm{~mm}$ \\
& $\begin{array}{l}\text { 10\% Cement replacement with FA } \\
\text { \& addition of CFRP + GFRP + SSF }\end{array}$ & $1: 2: 4$ & 0.5 & $5 \mathrm{~mm}$ \\
\end{tabular}

Legend: Carbon fiber reinforced polymer (CFRP), Glass fiber reinforced polymer (GFRP), Stainless steel fiber (SSF)

Table 5. Fineness modulus of sand.

\begin{tabular}{cccc}
\hline Sieve \# & $\begin{array}{c}\text { Weight retained } \\
\text { (grams) }\end{array}$ & $\begin{array}{c}\text { Cumulative weight } \\
\text { retained (grams) }\end{array}$ & $\begin{array}{c}\text { Cumulative weight } \\
\text { percentage retained (grams) }\end{array}$ \\
\hline $\mathbf{8}$ & 18 & 16 & 1.2 \\
16 & 40 & 57 & 7 \\
$\mathbf{3 0}$ & 75 & 120 & 10 \\
$\mathbf{5 0}$ & 130 & 260 & 25 \\
$\mathbf{1 0 0}$ & 540 & 800 & 78 \\
Pan & 200 & & \\
\hline
\end{tabular}

Result: Fineness Modulus $(\mathrm{FM})=1.24$. 


\section{Analysis of Test Results \& Discussion}

At first concrete specimens of conventional concrete as bases for comparison were cast. The concrete made by replacing cement and adding different fiber dosage reveled positive result showing increase in the mechanical properties of concrete when compared with the control one. Marked strength has been achieved in the concrete made by replacing cement with $10 \%$ of fly ash and by adding $1 \%$ of hybrid fibers. Addition of fibers significantly reduced the strength of concrete at curing period of 28 days.

\subsection{Compressive Strength Results}

Compressive strength test was done by using Tinius Olsen compression machine in concrete lab at the university of Toledo. The machine and specimen test setup can be seen in Figure 1 .

It can be observed from Figure 2, that the maximum compressive strength has been achieved when $1 \%$ of fibers added either separately or combined in the concrete mix. Sudden reduction in compressive strength was observed when higher dosage of fibers is added. It shows that the fibers are effective up to certain limit in enhancing the overall mechanical properties of concrete. Slight increase in compressive strength was achieved when one or more fibers added together. However, comparing with the control specimen the maximum strength obtained at $1 \%$ addition of hybrid fibers is $11 \%$ more (Table 6 ).

Table 6. Compressive strength test results.

\begin{tabular}{cccc}
\hline $\begin{array}{c}\text { Fibers } \\
\text { used }\end{array}$ & $\begin{array}{c}\text { Reinforcement } \\
\text { ratio }\end{array}$ & $\begin{array}{c}28 \text { days } \\
\text { strength }\end{array}$ & $\begin{array}{c}28 \text { days } \\
\text { strength }\end{array}$ \\
\hline- & $(\%)$ & $(\mathrm{Psi})$ & $(\mathrm{MPa})$ \\
0 & 0 & 3299.74 & 22.75 \\
CFRP & 1 & 3570.08 & 24.61 \\
CFRP & 1.5 & 3164.57 & 21.82 \\
CFRP + GFRP & 1 & 3649.60 & 25.16 \\
CFRP + GFRP & 1.5 & 3196.38 & 22.04 \\
CFRP + GFRP + SSF & 1 & 3705.26 & 25.55 \\
CFRP + GFRP + SSF & 1.5 & 2822.67 & 19.46 \\
\hline
\end{tabular}
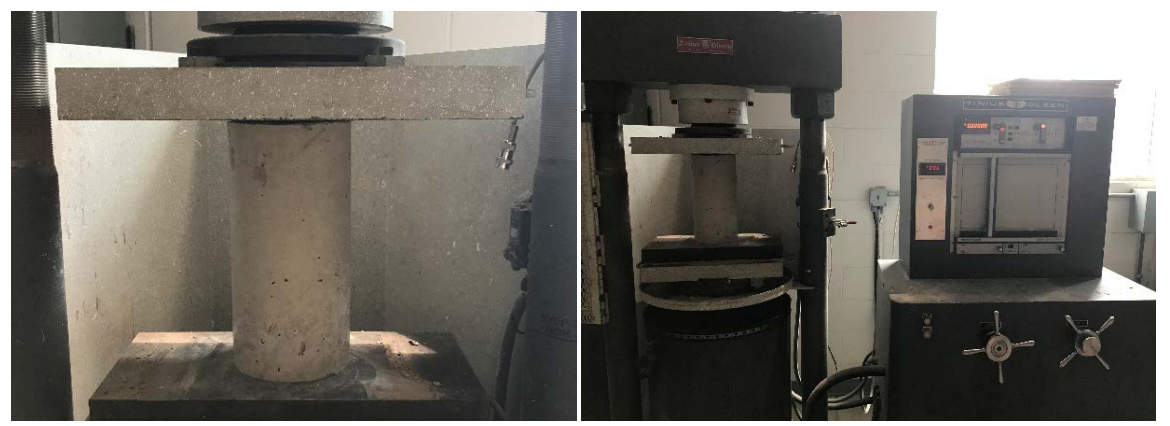

Figure 1. Compressive strength test machine and setup. 


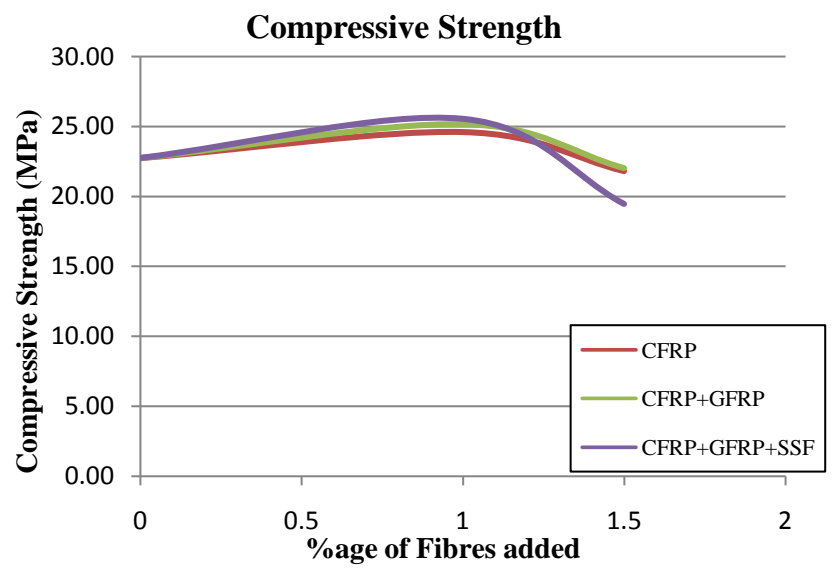

Figure 2. Compressive strength test results at 28 days.

\subsection{Tensile Strength Results}

Split tensile strength test was also done using Tinius Olsen compression machine in concrete lab at the university of Toledo. The test setup and specimen crack pattern can be seen in Figure 3.

Figure 4 shows split tensile strength results of concrete specimen after the curing period of 28 days. As compared to the control specimen, the results obtained are quite significant. Maximum tensile strength obtained was by adding $1 \%$ of hybrid fibers such as carbon fiber reinforced polymer (CFRP), glass fiber reinforced polymer (GFRP) and stainless steel fibers (SSF) in combination. The maximum tensile strength obtained was $26 \%$ more than the control specimen. Fibers used beyond $1 \%$ showed sudden reduction in tensile strength of concrete. It shows that the fibers are effective up to certain limit in enhancing the overall mechanical properties of concrete (Table 7).

\subsection{Crack Patterns and Failure of Specimens under Compression and Tension}

During the experiment, the initiation of the propagation of the cracks was observed before and after testing each specimen. Under the compression test, the cracks were mostly combination of inclined and vertical cracks along the height of cylinder. Crack initiation and propagation were different in specimens made with various fiber ratios. When different fibers were added in the concrete mix, less cracks were developed as compared to the control specimen. The failure pattern and development of cracks in specimens under compression can be observed in Figure 5.

Similarly, the specimens were tested under split tensile strength test. All the specimens were put horizontally to split them apart and to get the tensile strength. Tensile cracks in each specimen was initiated at the top and propagated to the bottom of the cylinder cross-section. Most of the cracks observed were vertical and can be seen in Figure 6. The crack width of each specimen was measured using Vernier caliper, the detail of which is given in Table 8. 
Table 7. Tensile strength test results.

\begin{tabular}{cccc}
\hline Fibers used & Reinforcement ratio & 28 days strength & 28 days strength \\
\hline- & $(\%)$ & $(\mathrm{Psi})$ & $(\mathrm{MPa})$ \\
0 & 0 & 431.74 & 2.98 \\
CFRP & 1 & 514.83 & 3.55 \\
CFRP & 1.5 & 552.60 & 3.81 \\
CFRP + GFRP & 1 & 530.73 & 3.66 \\
CFRP + GFRP & 1.5 & 518.80 & 3.58 \\
CFRP + GFRP + SSF & 1 & 582.41 & 4.02 \\
CFRP + GFRP + SSF & 1.5 & 558.56 & 3.85 \\
\hline
\end{tabular}

Table 8. Split tensile crack width.

\begin{tabular}{ccc}
\hline Fibers used & Reinforcement ratio & Split tensile crack width \\
\hline- & $(\%)$ & $(\mathrm{mm})$ \\
0 & 0 & 1.0 \\
CFRP & 1 & 0.9 \\
CFRP & 1.5 & 0.8 \\
CFRP + GFRP & 1 & 0.3 \\
CFRP + GFRP & 1.5 & 0.5 \\
CFRP + GFRP + SSF & 1 & 0.9 \\
\hline Control & &
\end{tabular}

Figure 3. Split tensile strength test setup and cracked pattern.

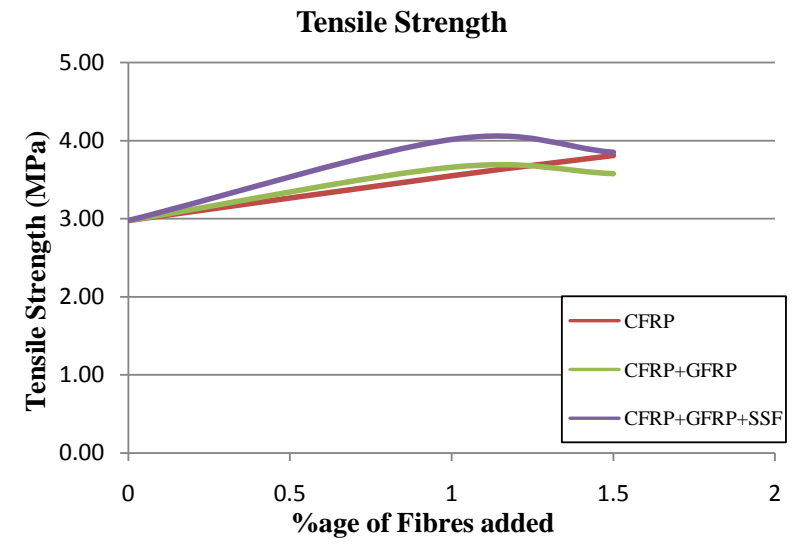

Figure 4. Split tensile strength results at 28 days. 


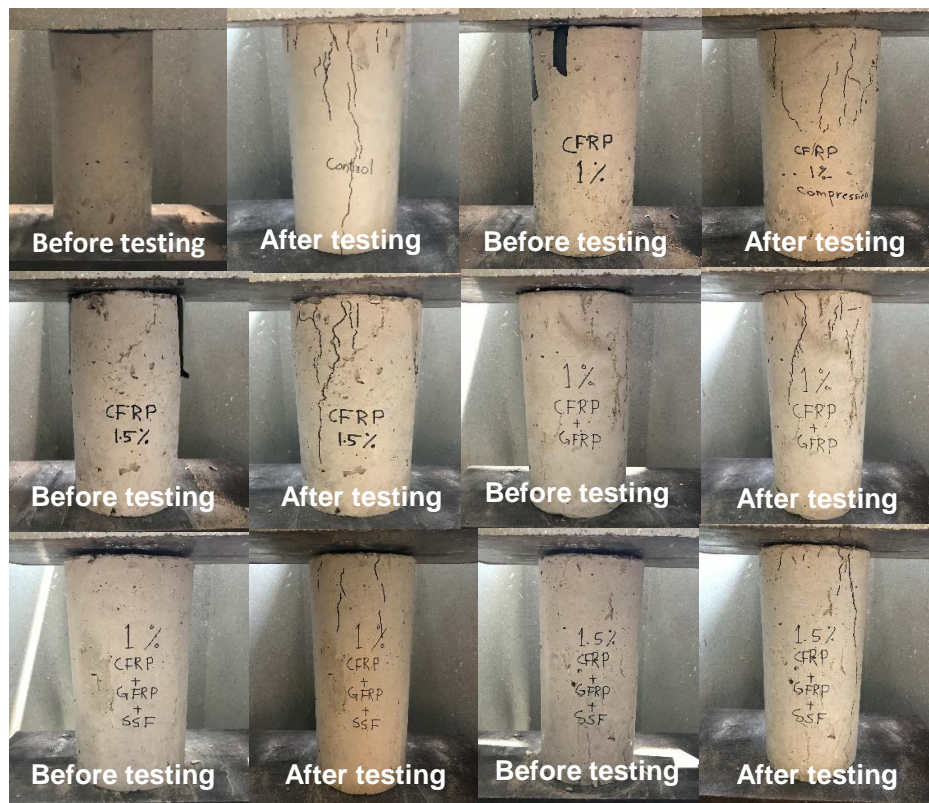

Figure 5. Crack pattern of each specimen before and after compression test.

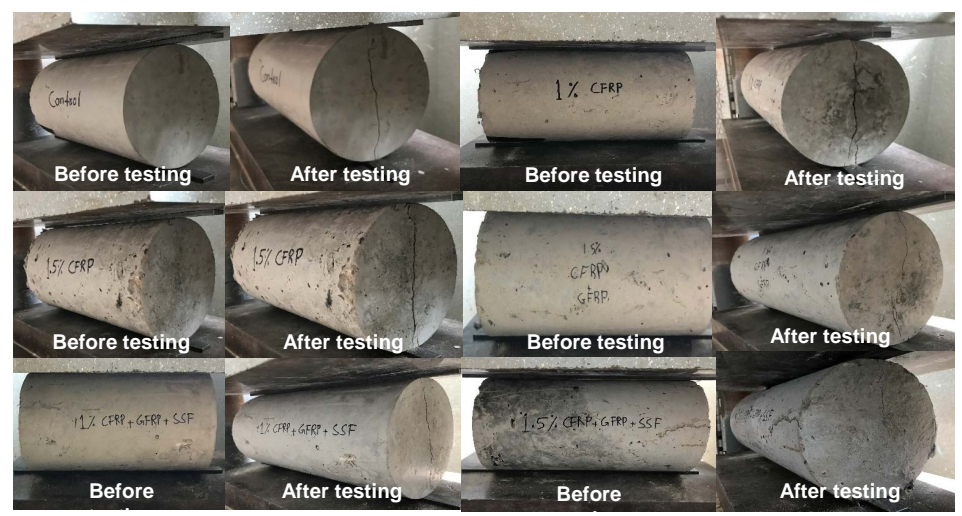

Figure 6. Crack pattern of specimen under Split tensile strength test.

\subsection{Observations}

In this experimental work, it was observed that by adding fibers in concrete is by far better than the control concrete specimen. It became obvious that $1 \%$ fiber reinforcement ratio was the optimal percentage in this study to enhance the mechanical properties of concrete. The $1 \%$ fiber reinforcement ratio threshold was also observed by [22] [23]. In general, concrete is inherently weak in tension, and to enhance the tensile strength fibers contribute at significant degree. This shows that, fibers made the cement concrete possible to behave up to some extent while undergoing tensile forces. Furthermore, it was observed that fibers showed post crack ductility which is nearly impossible in plain concrete specimens. The tested specimens were still strong enough since the fibers were holding the whole concrete mix together. It can be observed in Figure 7 that, cracks in control specimen are more severe compared to specimen made with hybrid fibers showing hair line cracks. 


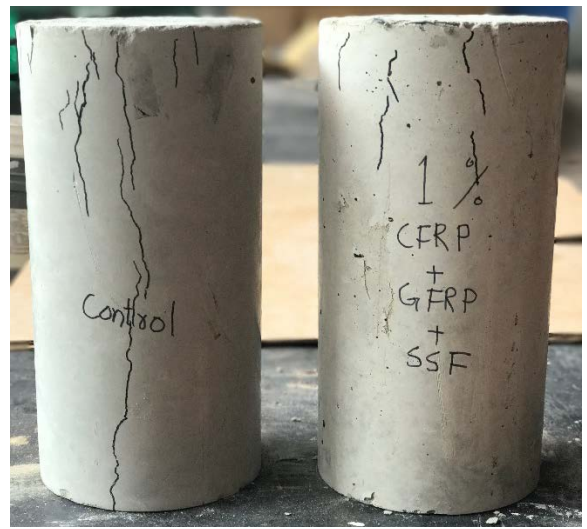

Figure 7. Crack pattern in control and hybrid fibre specimens.

Based on result obtained, addition of various fibers to concrete-fly ash mix can enhance the mechanical properties while, the use of fly ash in concrete reduces the negative effect on the environment. The two supplementary materials such as fibers and fly ash will result in cost saving through the life of structure.

\section{Recommendations}

1) There is a need to conduct elaborative research work on different fiber sizes and their effect on crack propagation.

2) Proper investigation regarding the behavior and reduction in the overall strength of concrete with further addition of fibers needs to be carried out.

3) Combination of different fibers with other cement replacing materials like sugarcane bagasse as (SCBA), metakolin, rice husk ash and silica fume by varying different water to cement ratio should be investigated.

4) Utilization of other fibers by and to study the effect of tensile strength by adding admixtures should be carried out.

5) Ductility of concrete using fibers in different cement concrete types like low to high strength along with cement replacement can be carried out.

\section{Conclusions}

The work done during this experiment is focused mainly on the mechanical properties of concrete, i.e. compressive and tensile strength by using $10 \%$ of fly ash as cement replacement and added fibers as reinforcement in the concrete mix. The results revealed that, fibers in concrete, increase both compressive and tensile strengths of tested concrete cylinders after the curing period of 28 days. More specifically the following conclusions are drawn:

1) The maximum compressive strength of concrete specimens made by replacing cement with $10 \%$ of fly ash and adding $1 \%$ of fibers increased the compressive strength of concrete by $11 \%$ when compared with the control specimen.

2) Similarly, the maximum tensile strength of concrete specimens made with replacing cement by $10 \%$ fly ash and adding $1 \%$ fibers enhanced the tensile 
strength of concrete quite significantly. The increase in tensile strength obtained was $26 \%$ more than the control specimen.

3) It was also observed that using fly ash and fibers particularly with higher reinforcement ratio of $1.5 \%$ reduced the workability of concrete. However, the workability could be enhanced by using admixtures i.e. air entraining, super plasticizers etc.

4) Fibers helped in enhancing the post crack ductile behavior which is almost absent in plain cement concrete. While testing the concrete specimens, it was observed that the fibers hold the concrete matrix up to considerable limit after being cracked not allowing the aggregates to disperse when tested.

5) Cement concrete made with $10 \%$ of fly ash as cement replacement and with $1 \%$ fiber reinforcement ratio shows that potentials to not only enhance the mechanical properties of cement concrete, but also will result in reduction in maintenance and life cycle cost and the impact on the environment.

\section{Acknowledgements}

The details of the research work presented in this manuscript were conducted in the concrete lab of Civil Engineering Department at the University of Toledo, College of Engineering in Ohio, USA. The authors are highly thankful to Dr. Luis Mata for his efforts and guidance and also to Owens and Corning's locally available fiber reinforced company for providing fibers which helped in making this research work possible. Thanks to the University of Toledo officials for providing cement, sand and coarse aggregate.

\section{Conflicts of Interest}

The authors declare no conflicts of interest regarding the publication of this paper.

\section{References}

[1] Patel, P.A., Atul, K.D. and Desai, A.J.D. (2012) An Investigation on Properties of Various Fibre Reinforced Concretes. International Journal of Advanced Engineering Research and Studies, 2, 36-38.

[2] Ulape, Y. and Narule, G. (2015) Experimental Investigation on Steel Fiber Reinforced Concrete Using Metakolin. International Journal of Emerging Technology and Advanced Engineering and Science, 5, 105-111.

[3] Sheetal, J.S.C., Mathew, M.D. and Jose, A.M. (2015) Experimental Study on Fiber Reinforced Concrete Using Lathe Scrap Fiber. International Journal of Advanced Technology in Engineering and Science, 3, 622-630.

[4] Revathi, S., Gandhimathi, R.S. and Saranya, S. (2016) Experimental Investigation on Mechanical Properties of Hybrid Fibres in M25 Grade Concrete. International Journal of Innovations in Engineering and Technology, 6, 213-220.

[5] Brijbhushan, S. and Maneeth, P.D. (2015) Experimental Investigation on Strength and Durability Properties of Hybrid Fiber Reinforced Concrete. International Research Journal of Engineering and Technology, 2, 891-896.

[6] Karahan, O. and Atis, C.D. (2011) The Durability Properties of Polypropylene Fiber 
Reinforced Fly Ash Concrete. Materials and Design, 32, 1044-1049.

[7] Indumathi, B. and Gnanadevi, V. (2015) An Experimental Investigation on Properties of Hybrid Fiber Reinforced Concrete with GGBS and Fly Ash. International Journal of Emerging Technology in Computer Science and Electronics, 13, 120-123.

[8] Kanagavel, R. and Arunachalam, K. (2018) Experimental Investigation on Mechanical Properties of Hybrid Fiber Reinforced Quaternary Cement Concrete. Journal of Engineered Fibers and Fabrics, 10, 139-147. https://doi.org/10.1177/155892501501000407

[9] Topcu, I.B. and Canbaz, M. (2007) Effect of Different Fibers on the Mechanical Properties of Concrete Containing Fly Ash. Construction and Building Materials, 21, 1486-1491. https://doi.org/10.1016/j.conbuildmat.2006.06.026

[10] Seshadri, R., Ramesh, B. and Niramala, S. (2016) A Study of High Performance Fiber Reinforced Polymers (FRP). International Journal of Innovative Research in Science, Engineering and Technology, 5.

[11] Vignesh, P., Krishnaraja, A.R. and Nandhaini, N. (2014) Study on Mechanical Properties of Geo Polymer Concrete Using M-Sand and Glass Fibers. International Journal of Innovative Research in Science, Engineering and Technology, 3, 110-116.

[12] Hsiea, M., Tu, C.J. and Song, P.S. (2008) Mechanical Properties of Polypropylene Hybrid Fiber-Reinforced Concrete. Materials Science and Engineering. A, 494, 153-157. https://doi.org/10.1016/j.msea.2008.05.037

[13] Song, P.S., Hwang, S. and Sheu, B.C. (2005) Strength Properties of Nylon- and Polypropylene-Fiber-Reinforced Concretes. Cement and Concrete Research, 35, 1546-1550. https://doi.org/10.1016/j.cemconres.2004.06.033

[14] Khoso, S., Wagan, F.H., Khan, J.S., Bhatti, N.K. and Ansari, A.A. (2014) Qualitative Analysis of Baked Clay Bricks Available in Larkana Region, Pakistan. Journal of Architecture Civil Engineering Environment, 7, 41-50.

[15] Basham, K.D., Clark, M., France, T. and Harrison, P. (2007) Fly Ash Is a Byproduct from Burning Pulverized Coal in Electric Power Generating Plants.

https://www.concreteconstruction.net/how-to/materials/what-is-fly-ash_o

[16] Khoso, S., Ansari, A.A. and Wagan, F.H. (2014) Investigative Construction of Buildings Using Baked Clay Post-Reinforced Beam Panels. Journal of Architecture Civil Engineering Environment, 7, 57-66.

[17] Khoso, S., Ansari, A.A., Khan, J.S. and Wagan, F.H. (2015) Experimental Study on Recycled Concrete Using Dismantled Road Aggregate and Baggase Ash. Proceedings of 7 th International Civil Engineering Congress (ICEC-2015), Sustainable Developments through Advancements in Civil Engineering, Karachi, Pakistan, 54-61.

[18] Khoso, S., Khan, J.S., Ansari, A.A. and Khaskheli, Z.H. (2016) Experimental Investigation on the Properties of Cement Concrete Partially Replaced by Silica Fume and Fly Ash. Journal of Applied Engineering Science, 14, 345-350.

https://doi.org/10.5937/jaes14-11116

[19] Keerio, M.A., Khoso, S., Khan, S.J., Ansari, A.A. and Bhatti, K.N. (2017) The Effect of Waste Glass as Partial Replacement of Cement on Properties of Concrete. Engineering Science and Technology International Research Journal, 1, 59-63.

[20] Khoso, S., Keerio, A.M., Ansari, A.A., Khan, J.S. and Bangwar, K.D. (2017) Effects of Rice Husk Ash and Recycled Aggregates on Mechanical Properties of Concrete. International Journal of Scientific and Engineering Research, 8, 1832-1835.

[21] Saand, A., Keerio, M.A., Juj, R., Khoso, S. and Bangwar, D.K. (2017) Utilization of Waste Glass as Partial Replacement of Fine Aggregate in Concrete. Engineering 
Science and Technology International Research Journal, 1, 28-31.

[22] Khoso, S., Naqash, M.T., Sher, S. and Saeed, Z. (2018) An Experimental Study on Fiberly Reinforced Concrete Using Polypropylene Fibre with Virgin and Recycled Road Aggregate. Architecture, Civil Engineering, Environment, 11, 73-80. https://doi.org/10.21307/ACEE-2018-007

[23] Kumar, V. and Kumar, R. (2016) An Experimental Study on Partial Replacement of Coarse Aggregate by Iron Slag with Polypropylene Fiber. International Journal of Science and Research (IJSR), 5, 212-216.

[24] State of the Art Report on Fiber Reinforced Concrete Reported by ACI Committee, 544. 